\title{
THE EFFECT OF PROFESSIONAL ATTITUDES OF NURSES WORKING IN DIFFERENT AREAS ON THE COMPLIANCE WITH ISOLATION PRECAUTIONS
}

Farklı Alanlarda Çalışan Hemşirelerin Profesyonel Tutumlarının İzolasyon Önlemleri Uyumlarına Etkisi Nihal ÜNALDI BAYDIN ${ }^{1}$, Esra TURAL BÜYÜK ${ }^{2}$, Büşra PAZARLI ${ }^{3}$

\section{ABSTRACT}

Objective: This research was conducted as a descriptive and cross-sectional study in order to determine the effect of professional attitudes of nurses working in different areas on the compliance of isolation precautions.

Materials and Methods: This study was a correlational, crosssectional and descriptive design and was conducted with 351 nurses employed in a university hospital in the north of Turkey. The data were collected through a questionnaire prepared by the researchers and the Inventory of Professional Attitude at Occupation and a Scale Compliance with Isolation Precautions. The data were collected between March and May 2019. In the analysis of the data, $t$ test, Kruskal-Wallis test, Mann Whitney $\mathrm{U}$ test and variance analysis (ANOVA) were used.

Results: $94 \%$ of the nurses received training on health carerelated infections. It was observed that professional attitude at occupation was higher in nurses over the age of 41 , single, having a 16-20 years of clinical experience and working as nurse manager, and showed statistically significant difference ( $p<0.05$ ). In addition, it was observed that nurses working in intensive care units were more compliance with isolation precautions than nurses working in other fields and showed a statistically significant difference ( $\mathrm{p}<0.05)$. It was detected that scale compliance with isolation precautions mean score of the nurses was $61.16 \pm 4.70$ and professional attitude at occupation scale mean score was $135.77 \pm 17.17$, and there was a significant, positively and weak relationship between the two scales $(r=0.148, \mathrm{p}<0.000)$.

Conclusion: Although the nurses' professional attitude score averages were high, compliance with the isolation measures was above the average. In the study, it was determined that the professional attitude score of the nurses was high, and some sociodemographic characteristics of the nurses affect their professional attitudes.

Keywords: Nurse; Compliance with isolation measures; Professional attitude

\section{ÖZET}

Amaç: $\mathrm{Bu}$ araştırma, farklı alanlarda çalışan hemşirelerin profesyonel tutumlarının izolasyon önlemlerine uyumuna etkisini belirlemek amacıyla tanımlayıcı ve kesitsel bir çalışma olarak gerçekleștirilmiştir.

Gereç ve Yöntemler: $\mathrm{Bu}$ çalışma ilişkisel, kesitsel ve tanımlayıcı bir tasarımda olup, Türkiye'nin kuzeyinde bir üniversite hastanesinde çalışan 351 hemşirenin oluşturduğu örneklemde gerçekleştirilmiştir. Veriler, araştırmacılar tarafindan hazırlanan anket formu, Meslekte Profesyonel Tutum Envanteri ve İzolasyon Önlemlerine Uyum Ölçeği ile Mart-Mayıs 2019 tarihleri arasında toplanmıştır. Verilerin analizinde t testi, Kruskal-Wallis testi, Mann Whitney U testi ve ANOVA testi kullanılmıştır.

Bulgular: Hemşirelerin \%94'ü hastane enfeksiyonları ile ilgili eğitim almışlardır. Mesleki profesyonel tutumun 41 yaş üzeri, bekar, 16-20 yıl klinik deneyimi olan ve sorumlu hemşire olarak görev yapan hemşirelerde daha yüksek olduğu ve istatistiksel olarak anlamlılık gösterdiği $(p<0.05)$. Ayrıca yoğun bakımda çalışan hemşirelerin diğer alanlarda çalışan hemşirelere göre daha fazla izolasyon önlemlerine uyumunun olduğu ve istatistiksel olarak anlamlılık gösterdiği belirlenmiştir $(p<0.05)$. Hemşirelerin İzolasyon Önlemleri Uyumu ölçeği puan ortalaması $61.16 \pm 4.70$ ve meslekte profesyonel tutum ölçeği puan ortalaması 135.77 \pm 17.17 saptanmış olup iki ölçek arasında anlamlı, pozitif yönde ve zayıf bir ilişki olduğu görülmüştür $(r=0.148, p<0.000)$.

Sonuç: Hemşirelerin mesleki tutum puan ortalamaları yüksek olmasına rağmen izolasyon ölçütlerine uyumu ortalamanın üzerindedir. Araştırmada hemşirelerin mesleki tutum puanlarının yüksek olduğu ve hemşirelerin bazı sosyodemografik özelliklerinin mesleki tutumlarını etkilediği belirlenmiştir.

Anahtar kelimeler: Hemşire; İzolasyon önlemlerine uyum; Profesyonel tutum

\footnotetext{
Makale Geliş / Received: 24.02.2021

Makale Kabul / Accepted: 17.03.2021

${ }^{1}$ Department of Nursing Administration, Faculty of Health Sciences, Ondokuz Mayis University, Samsun, Turkey

ORCID: 0000-0002-5074-6922, e- posta: unaldin25@gmail.com

${ }^{2}$ Department of Child Health Nursing, Faculty of Health Sciences, Ondokuz Mayıs University, Samsun, Turkey

ORCID: 0000-0001-8855-8460, e- posta: esratural55@gmail.com

${ }^{3}$ Faculty of Health Sciences, Ondokuz Mayıs University Kurupelit Campus, ORCID: 0000-0002-2261-8894

e-posta: busrapazarli@hotmail.com

Sorumlu Yazar: Esra TURAL BÜYÜK
} 


\section{INTRODUCTION}

Professional attitude is defined as "feelings and opinions that pursue the goals of a profession and help create professional behavior". Professionalism at occupation is turning personal professionalism into corporate professionalism (Çelik et al., 2012; Ghadirian et al., 2014). Since the technological and political developments in recent years have also affected the health system, the nursing profession is going through a process from traditional nursing model to professionalism (Erol \& Türk, 2019). Professionalism at occupation plays an important role in the profession becoming attractive and prestigious in the society, the members of the profession being respected and continuity of the profession (Karadağ et al., 2007; Ten et al., 2014). Professionalism in nursing is a complex, variable and dynamic process (Ten et al., 2014; Ghadirian et al., 2014). A professional nurse is a nurse who integrates intellectual knowledge, skill and attitude accumulation and theoretical knowledge with practice, can benefit from this knowledge in her studies in protective and therapeutic healthcare field; has the ability to get to the root of the problem, judge, make decision and solve problem; has the capability to provide quality care; has the training and managing capacity (Ghadirian et al., 2014; Doost et al., 2016). Determining the level of professionalism in nursing and carrying out forward improvement studies is important in terms of increasing the value given to the profession. (Çelik et al., 2012; Ten et al., 2014). Furthermore, it is stated that the development of professional attitude among profession members will contribute to the increase of the quality of care, professional unity and professional status (Tanaka et al., 2015; Erol \& Türk, 2019). Professional attitudes of nurses are reflected in patient care. The quality of the care provided by the nursing services in accordance with the quality standards in hospitals is evaluated with various indicators (pressure ulcer rate, fall rate, medication errors, etc.). One of the care indicators is health care-related infections rates. Health care-related infections have undesirable consequences such as morbidity, mortality, extension of hospital stay and increased treatment costs (Lombarts et al, 2014; Suliman et al., 2018; Lobo et al., 2019). The inevitable way to prevent them is through isolation precautions and compliance with these precautions. Prevention of health care-related infections is a process that begins with the admission of the patient to the hospital and continues until discharged. Since the most important stage in preventing health care-related infections is isolation precautions, healthcare professionals, especially nurses who provide one-to-one care and intervention to patients, should know these precautions very well and reflect them to their practices (Arli \& Bakan., 2017; Şatır Güleç et al., 2019; Lindberg et al, 2019). The worldwide incidence of healthcare-associated infections varies between $7 \%$ and 10\%. (https://www.healthypeople.gov/2020/topics-objectives/topic/healthcare-associated-infections ). It is reported that the annual incidence of these infections varies between 5-10\% in the USA, between 6-9\% in Europe and between 1-16\% in Turkey (Özden and Özveren, 2016). It is also estimated that 1.5 million deaths occur worldwide due to healthcare-associated infections each year (https://hsgm.saglik.gov.tr/tr/bulasicihastaliklar/shie/shie-liste/shie.html.). Healthcare-associated infections cause long-term hospitalizations and therefore additional costs in the healthcare system. In a study conducted, it was stated that as the ages of hospitalized patients decrease, the cost of healthcare-associated infections increases and this may be due to the more complex and more severe course of diseases in infants and children (Ağırbaş et al.,2015). In addition, these infections cause morbidity and mortality, leading to workforce losses in employees and increase the risk of error and burnout with increased workload, consequently increasing the rate of healthcare-associated infections (Çelik et al.,2020).Therefore, nurses are expected to receive in-service training on compliance with isolation precautions and to fulfill the necessary responsibilities accordingly. It is also emphasized that nurses should know that health care-related infections are preventable, they should know the internationally applied standard precautions and precautions for transmission routes, and that they should offer patient care accordingly (Kaushal et al.,2015; Karahan et al., 2019).

Nurses, who are in constant contact with the patient and responsible for care, have a more effective role in the formation, spread and prevention of infections than other healthcare staff. Failure to pay attention to care practices requiring professional at occupation due to the unhygienic care practices of nurses, high number of patients per nurse and poor hand washing behaviors may cause health care-related infections (Lindberg et al.,2019; Şatır Güleç et al., 2019). In this context, there is no study encountered in the literature investigating the relationship between nurses' professional attitudes with isolation precautions compliance, which has an important role in the occurrence of health care-related infections.

This study was carried out to determine the effect of professional attitudes of nurses working in a university hospital on the isolation precautions compliance.

\section{Research questions:}

- What is the level of professional attitudes at occupation of nurses?

- What is the level of nurses' compliance with isolation precautions?

- Is there a relationship between some characteristics of nurses and their professional attitudes and compliance with isolation precautions?

- Is there a relationship between professional attitudes and isolation compliance of nurses? 


\section{METHODS}

Study Design: This study was planned using a cross-sectional, descriptive and correlational design.

Study Setting and Sample: This study was conducted in the pediatric clinics of a university hospital in the northern region of Turkey between March 6, 2019 and May 27, 2019. The study population included 440 nurses fitting the study inclusion criteria of working in clinics for at least one year. The study sample included 351 nurses and the participation rate was $80 \%$.

Study Instruments: Study data were collected using a Personal Information Form, Inventory of Professional Attitude at Occupation (IPAO) and Scale Compliance with Isolation Precautions (SCIP).

Personal Information Form: The form consisted of 10 questions to determine the age, gender, marital status, education level, position, total time of proffesion, unit, training status about isolation and the problems they experienced in applying isolation precautions (Tayran and Ulupınar, 2011; Satır Güleç et al.,2019).

Inventory of Professional Attitude at Occupation (IPAO): IPAO was developed by Erbil and Bakır (2009). Items in inventory are rated as "Fits me completely": 5, Fits me a little ": 4; "Neutral": 3; "Doesn't fit me": 2; "It does not fit me definitely: 1 point". The lowest point which can be obtained from VPAI is 32 and the highest 160. As the score obtained from the inventory increases, the level of professionalism increases. The Cronbach Alpha coefficient of VPAI, developed by Erbil and Bakır, was determined to be 0.89, but the Cronbach Alpha coefficient to be 0.95 in this study.

Scale Compliance with Isolation Precautions (SCIP): The scale, developed by Tayran and Ulupinar (2010), consists of 18 items. Scale was 5 point likert scale, rated as Strongly disagree: 1 point, Disagree: 2 points, No idea: 3 points, Agree: 4 points, Strongly agree: 5 points. The scale consisted of 4 sub-dimensions: mode of transmission, employee-patient safety, environmental control and hand washing-gloves. The 5th, 7th, 12th and 17th items in the scale were negative and scored in reverse. The lowest total score that can be obtained from the scale was 18 , and the highest total score was 90 . While Cronbach alpha value was determined as 0.85 by Tayran and Ulupinar, it was found as 0.72 in this study.

Data Collection: Researchers distributed surveys in envelopes to the nurses working in the hospitals where the studies were conducted. Nurses completed the surveys within 15-20 minutes in separate rooms to prevent interaction among participants. No payment was made to the nurses for involvement in the survey.

Statistical Analysis: The data obtained from the study were evaluated using the SPSS 20.0 software program. During data analysis, frequencies and percentages were used to analyze the sociodemographic characteristics of the nurses. The Kolmogorov-Smirnov test was used to determine whether the data were distributed normally. Number, percentage, mean, standard deviation, and median were used for descriptive statistics. Parametric tests (the independent two-sample t-test, one-way analysis of variance (ANOVA), and Tukey's test) were used to analyze data with normal distribution and nonparametric tests (Mann-Whitney $\mathrm{U}$ and Kruskal-Wallis tests) were used to analyze data without normal distribution. Pearson's correlation analysis was performed to investigate possible correlations between Inventory of Professional Attitude at Occupation and Scale Compliance with Isolation Precautions. For all the analyses, $\mathrm{p}<0.05$ was considered statistically significant.

Ethical Considerations: The study was conducted after formal permission for the study was obtained from the Directorates of the Hospitals and the Ethics Commission of the university hospital (IRB file no: OMU-KAEK B.30.2.ODM.2.20.08/1598-1674).

\section{RESULTS}

$50.1 \%$ of the nurses included in the study are between $20-30$ years old, $63 \%$ are married, $97.7 \%$ are women, $90.6 \%$ have bachelor's degree, $93.4 \%$ are clinical nurses, $35.9 \%$ are working in surgical units and $40.2 \%$ of them have 1-5 years of professional experience (Table 1). 
Table 1. Some Descriptive Characteristics of Nurses (N:351)

\begin{tabular}{llcc}
\hline Characteristics & & Number (n) & Percentage (\%) \\
\hline Age & $20-30$ years & 176 & 50.1 \\
& $31-40$ years & 123 & 35 \\
Marital status & 41 years and above & 52 & 14.8 \\
Gender & Married & 221 & 63 \\
& Single & 130 & 37 \\
Educational Level & Female & 343 & 97.7 \\
& Male & 8 & 2.3 \\
& High school & 10 & 2.8 \\
& Associate degree & 13 & 3.8 \\
Position & Bachelor's Degree & 318 & 90.6 \\
& Post graduate & 10 & 2.8 \\
& Nurse manager & 23 & 6.6 \\
Unit & Clinical nurse & 328 & 93.4 \\
& Internal medicine clinics & 92 & 26.2 \\
Professional Time & Surgical clinics & 126 & 35.9 \\
& Pediatrics clinics & 65 & 18.5 \\
& Intensive care units & 44 & 12.5 \\
& Emergency units & 24 & 6.8 \\
& $1-5$ years & 141 & 40.2 \\
& 6-10 years & 75 & 21.4 \\
& $11-15$ years & 53 & 15.1 \\
& $16-20$ years & 51 & 14.5 \\
\hline
\end{tabular}

$94 \%$ of the nurses stated that they received in-service training on isolation. Nurses stated that they had problems with $57 \%$ of the physicians and $48.4 \%$ of the patients about the incompliance of the isolation precautions, furthermore, $47.3 \%$ of the nurses had problems with providing separate isolation rooms in the clinic and $42.7 \%$ with lack of equipment in applying isolation precautions (Table 2).

Table 2. Training Status of Nurses and Experienced Problems in Practicing Isolation Precautions (N:351)

\begin{tabular}{lcccc}
\hline & \multicolumn{3}{c}{ Yes } & \multicolumn{2}{c}{ No } \\
\cline { 2 - 5 } & $\mathbf{n}$ & $\mathbf{\%}$ & n & \% \\
\cline { 2 - 5 } Status of training on isolation precautions & 330 & 94 & 21 & 6 \\
\hline Problems faced/experienced in applying isolation precautions * & & & & \\
Hygienic hand washing & 64 & 18.2 & 287 & 81.8 \\
Correct use of gloves, apron, protective glasses and mask & 92 & 26.2 & 259 & 73.8 \\
Separation of common use equipments & 132 & 37.6 & 219 & 62.4 \\
Providing sterilization-disinfection & 55 & 15.7 & 296 & 84.3 \\
Providing separate isolation room in the clinic & 185 & 52.7 & 166 & 46.3 \\
Ensuring cleanliness of the isolation room & 81 & 23.1 & 270 & 76.9 \\
Providing the transport of the patient to be isolated, admission to the & 74 & 21.1 & 277 & 78.9 \\
service/unit & & 57 & 151 & 43 \\
Physician's incompliance with isolation precautions & 69 & 19.7 & 282 & 80.3 \\
Nurse's incompliance with isolation precautions & 170 & 48.4 & 181 & 51.6 \\
Patient's incompliance with isolation precautions & 111 & 31.6 & 240 & 68.4 \\
Insufficient institutional standards/instructions & 49 & 14 & 302 & 86 \\
Inadequate communication with hospital infection control committee & 49 & & \\
members & 150 & 42.7 & 201 & 57.3 \\
Lack of equipment & & & & \\
\hline
\end{tabular}

* Multiple choices are marked. 
The Inventory of Professional Attitude at Occupation score was 135.77 \pm 17.17 (min:74-max:159). Scale Compliance with Isolation Precautions total mean score of the nurses included in the study was $61.16 \pm 4.70$ (min:34-max:74), and in the sub-scales; mode of transmission subscale mean score was found 16.71 \pm 2.58 (5$25)$, employee and patient safety subscale mean score $20.18 \pm 1.90$ (15-25), environmental control subscale mean score $14.02 \pm 1.92$ (4-20), hand hygiene, glove use subscale mean score 10.20 \pm 0.94 (7-13). (Table 3).

Table 3. Descriptive Statistics of Scale Compliance with Isolation Precautions and Inventory of Professional Attitude at Occupation of Nurses (N:351)

\begin{tabular}{|c|c|c|c|c|}
\hline Variables & Mean (SD) & Median & Min. & Max. \\
\hline Inventory Of Professional Attitude At Occupation & $135.77(17.17)$ & 140 & 74 & 159 \\
\hline Scale Compliance with Isolation Precautions & $61.16(4.70)$ & 61 & 34 & 74 \\
\hline Mode of transmission & $16.71(2.58)$ & 17 & 5 & 25 \\
\hline Employee and patient safety & $20.18(1.90)$ & 20 & 15 & 25 \\
\hline Environmental control & $14.02(1.92)$ & 14 & 4 & 20 \\
\hline Hand hygiene - use of gloves & $10.20(0.94)$ & 10 & 7 & 13 \\
\hline
\end{tabular}

When the distribution of the mean scores obtained from the scales according to the descriptive characteristics of the nurses is examined, the Inventory of Professional Attitude At Occupation mean scores are higher and showed statistically significant difference in nurses over the age of 41, having 16-20 years of clinical experience, working as nurse manager and working in pediatrics clinics $(\mathrm{p}<0.05)$ (Table 4). In addition, it was determined that the nurses working in intensive care units had higher mean scores in compliance with isolation precautions compared to nurses working in other fields and this situation showed a statistically significant difference $(\mathrm{p}<0.05)$. It was determined that there was no significant difference between the age, position and profession time of the nurses and the scale of compliance with isolation precautions, and their mean values were close to each other $(\mathrm{p}>0.05)$ (Table 4$)$.

Table 4. Distribution of Scores Averages of Some Nurses' Descriptive Characteristics with Inventory Of Professional Attitude At Occupation and Scale Compliance with Isolation Precautions (N:351)

\begin{tabular}{|c|c|c|c|c|c|}
\hline \multirow[b]{2}{*}{ Variables } & & \multicolumn{2}{|c|}{$\begin{array}{c}\text { Inventory Of Professional Attitude } \\
\text { At Occupation }\end{array}$} & \multicolumn{2}{|c|}{$\begin{array}{c}\text { Scale Compliance with Isolation } \\
\text { Precautions }\end{array}$} \\
\hline & & $\begin{array}{l}\text { Mean } \pm \text { SD/Media } \\
\text { n (min-max) }\end{array}$ & $\begin{array}{c}\text { Test statistic } \\
\text { p } \\
\end{array}$ & $\begin{array}{c}\text { Mean } \pm \text { SD/Media } \\
\text { n (min-max) }\end{array}$ & $\begin{array}{c}\text { Test } \\
\text { statistics } \\
\mathbf{p} \\
\end{array}$ \\
\hline Age & $\begin{array}{l}20 \text { - } 30 \text { years } \\
31-40 \text { years } \\
41 \text { years and above }\end{array}$ & $\begin{array}{l}135.32 \pm 17.41 \mathrm{a} \\
135.15 \pm 17.03 \mathrm{a} \\
141.73 \pm 14.38 \mathrm{~b}\end{array}$ & $\begin{array}{l}F=3.272 \\
p=0.039\end{array}$ & $\begin{array}{l}61.13 \pm 5.10 \\
61.63 \pm 4.84 \\
61.15 \pm 3: 26\end{array}$ & $\begin{array}{l}F=0.427 \\
p=0.653\end{array}$ \\
\hline $\begin{array}{l}\text { Marital } \\
\text { status }\end{array}$ & $\begin{array}{l}\text { Married } \\
\text { Single }\end{array}$ & $\begin{array}{l}131.91 \pm 18.23 \\
137.25 \pm 15.18\end{array}$ & $\begin{array}{l}\mathrm{t}=6.605 \\
\mathrm{p}=0.01\end{array}$ & $\begin{array}{l}61.42 \pm 4.37 \\
61.12 \pm 5.31\end{array}$ & $\begin{array}{l}t=0.100 \\
P=0.752\end{array}$ \\
\hline Position & $\begin{array}{l}\text { Nurse manager } \\
\text { Clinical nurse }\end{array}$ & $\begin{array}{l}147.22 \pm 10.16 \\
135.44 \pm 17.10\end{array}$ & $\begin{array}{l}\mathrm{t}=8.248 \\
\mathrm{p}=0.004\end{array}$ & $\begin{array}{l}59.78 \pm 6.23 \\
61.41 \pm 4.65\end{array}$ & $\begin{array}{l}\mathrm{t}=0.215 \\
\mathrm{p}=0.643\end{array}$ \\
\hline & $\begin{array}{l}\text { Internal medicine } \\
\text { Surgery }\end{array}$ & $\begin{array}{l}133.65 \pm 17.12 \mathrm{a} \\
136.83 \pm 18.13 \mathrm{ab}\end{array}$ & $\begin{array}{l}\mathrm{F}=10.790 \\
\mathrm{P}=0.029\end{array}$ & $\begin{array}{l}60.30 \pm 3.70 \mathrm{a} \\
61.68 \pm 4.17 \mathrm{~b}\end{array}$ & $\begin{array}{l}F=17.51 \\
p=0.002\end{array}$ \\
\hline Unit & $\begin{array}{l}\text { Pediatrics } \\
\text { Intensive care unit } \\
\text { Emergency }\end{array}$ & $\begin{array}{l}140.05 \pm 16.09 \mathrm{~b} \\
137.82 \pm 13.68 \mathrm{ab} \\
129.46 \pm 15.62 \mathrm{a}\end{array}$ & & $\begin{array}{l}61.66 \pm 4.95 \mathrm{ab} \\
62.23 \pm 7.48 \mathrm{~b} \\
60.50 \pm 4.18 \mathrm{ab}\end{array}$ & \\
\hline $\begin{array}{l}\text { Length of } \\
\text { professional } \\
\text { experience }\end{array}$ & $\begin{array}{l}1-5 \text { years } \\
6-10 \text { years } \\
11-15 \text { years } \\
16-20 \text { years } \\
21 \text { years and above }\end{array}$ & $\begin{array}{l}134.89 \pm 17.31 \mathrm{a} \\
131.91 \pm 17.61 \mathrm{a} \\
136.25 \pm 16.87 \mathrm{ab} \\
142.37 \pm 14.87 \mathrm{~b} \\
142.42 \pm 13.27 \mathrm{~b}\end{array}$ & $\begin{array}{l}F=16.737 \\
p=0.002\end{array}$ & $\begin{array}{l}60.74 \pm 5.14 \\
61.87 \pm 4.62 \\
61.94 \pm 5.14 \\
61.41 \pm 3.87 \\
61.23 \pm 4.00\end{array}$ & $\begin{array}{l}F=2.843 \\
p=0.584\end{array}$ \\
\hline
\end{tabular}

a-b: There is no difference between groups with the same letter. 
$\mathrm{F}=$ One-way analysis of variance and Tukey test, $\mathrm{t}=$ Independent Two-Sample $\mathrm{t}$ test

When the relationship between professional attitudes of nurses and the compliance with isolation precautions was examined in the study, it was found that there was a significant, positive and weak correlation between the professional attitudes and the compliance with isolation precautions of nurses $(r=0.148, p<0.000)$ (Table 5).

Table 5. Correlation Values Between Total Inventory of Professional Attitude At Occupation and Total of Scale Compliance with Isolation Precautions $(\mathbf{n}=351)$

\begin{tabular}{lccc}
\hline & & \multicolumn{2}{c}{ Scale Compliance with Isolation Precautions } \\
\hline Inventory Of Professional & & $\mathbf{r}_{\mathrm{s}}$ & $0.148^{* *}$ \\
Attitude At Occupation & Spearman & $\mathbf{p}$ & $\mathbf{0 . 0 0 0}$ \\
\hline rs=Spearman correlation analysis & & & \\
$\mathrm{r}=0.00-0.25$ very weak, $\mathrm{r}=0.26-0.49$ & weak, $\mathrm{r}=0.50-0.69$ & medium, $\mathrm{r}=0.70-0.89$ high, $\mathrm{r}=0.90-1.00$ very high \\
DISCUSSION & &
\end{tabular}

In the study, it was found that the professional attitude mean score of the nurses was high (Table 3). In the studies conducted in Turkey, it was detected that the professional attitude of nurses was higher in some studies (Zengin et al., 2018), while it was lower in some others (Çelik ve Hisar, 2012; Doost et al., 2016;). This difference can be attributed to the execution of these studies in different working environments, samples and time periods.

In the study, it was observed that the nurses over 40 years of age, single, with 16-20 years of clinical experience, working as nurse manager and working in pediatric units have higher professional attitudes (Table 4). In studies conducted, professional attitudes of nurses over the age of 40 (Ghadirian et al., 2014; Doost et al., 2016), with long clinical experience (Tanaka et al., 2015; Doost et al., 2016; Zengin et al., 2018; Çelik and Hisar; 2012), working as first-line nurse manager (Çelik and Hisar; 2012; Tanaka et al., 2015) and working in pediatric units (Zengin et al., 2018) were found to be higher. It is thought that the increase in the professional time and experience also increases the individual development. It can be thought that higher level of education and professional experince of the first-line nurse manager, and their duties and responsibilities undertaken, stimulates the professionalism at occupation. It is also thought that the nurses working in pediatrics units may have a high level of satisfaction with the unit and therefore it may affect their professional attitudes positively. It is also thought that the fact that the patient group cared for is a very sensitive focus such as infants and children and associated care behaviors specific for paediatrics may be effective in the reason why nurses working in pediatric units show more positive professional attitudes than nurses working in other units.

In the study, it was determined that the mean score of the nurses on the Scale Compliance with Isolation Precautions was moderately $61.16 \pm 4.70$. Although the majority of nurses stated that they received in-service training on isolation precautions, the compliance with isolation precautions was found to be above average (Table 2).Similar to the findings of this study, moderate scores were obtained in some studies (Pereira et al,2013; Mohammadzadeh et al,2013; Alotaibi et al,2017; 2018; Şatır Güleç et al., 2019). Although most of the nurses in the study stated that they had received training on isolation measures, their low level of attitudes towards compliance with isolation measures suggests that knowledge may have a limited effect on creating behavior and attitude.

Considering the literature, it was seen that the healthcare team who received in-service training in isolation showed more compliance with the isolation precautions (Allen and Cronin, 2012; Karahan et al., 2019). In a study conducted in Vietnam, it was determined that there was a moderate positive relationship between nurses' knowledge of isolation precautions and their attitudes towards isolation (Thu et al., 2012). In some studies, however, it has been determined that in-service training status does not affect the compliance with isolation precautions (Suliman et al., 2018; Alkan Çeviker et al., 2019; Lobo et al., 2019). In a study conducted in Jordan, it was reported that although nurses have a good level of knowledge on isolation precautions (90\%), only $65 \%$ of nurses complied well with isolation precautions (Suliman et al., 2018). In the study of Alkan Çeviker et al. (2019), it was found that all of the intensive care nurses did not have sufficient information for infection specific isolation precautions, although they received training from the infection control committee nurse. Studies show that education improves knowledge and attitude positively and changes behavior in a limited way; therefore, it has been reported that periodic repetition of in-service training will increase compliance.

It was determined that, in terms of compliance with isolation precautions, nurses mostly experienced problems with incompliance with isolation precautions of physicians, inability to provide separate isolation rooms in the clinic, incompliance with isolation precautions of patients, and lack of equipment (Table 2). It is thought that this result may be due to insufficient infrastructure in the hospital and the fact that nurses feel more 
responsible about compliance with isolation measures when compared with patients and other healthcare professionals, especially physicians. In some studies, similar to the result of this study, it was found that healthcare staff had problems in compliance with isolation precautions (Y1ldırım et al., 2015; Abukan et al., 2016; Şatır Güleç et al., 2019; Karahan et al., 2019). In addition, it was stated that nurses have problems in applying isolation precautions due to lack of equipments and there are no separate isolation rooms in the hospitals they work due to institutional deficiencies (Tayran and Ulupınar, 2011; Şatır Güleç et al., 2019).

In the study, it was observed that nurses working in intensive care units showed more compliance with isolation precautions than nurses working in other fields $(\mathrm{p}<0.05)$. Similarly, it was found in the studies that nurses working in intensive care units showed more compliance with isolation precautions (Erden et al., 2015; Arli and Bakan, 2017; Şatır Güleç et al., 2019). Intensive care units (ICU) are among the clinics where health care-related infections are most common. Therefore, it is extremely important to comply with isolation precautions in the prevention of health care-related infections seen in ICU (Pereiara et al.,2013,Kirtil \& Akyüz, 2018). It is thought that the compliance of the nurses working in this unit with the isolation precautions is higher than the nurses working in other units, since nurses working in intensive care units have more up-to-date information on the prevention and control of infections and are the ones providing the most effective care to patients who have the potential to apply this information. Furthermore, it is thought that the intensive care units are special areas that is closely monitored in hospitals due to the follow-up of health care-related infections in accordance with the quality standards, and this increases the compliance of the healthcare team working in these areas with the isolation precautions.

In the study, it was seen that there was a significant, positive and weak relationship between the professional attitudes at occupation and the compliance with isolation precautions of the nurses (Table 5). Analyzing the literature, no studies were encountered regarding the relationship between nurses' professional attitudes and compliance with isolation precautions. It was found in a study that nurses who adopt patient safety culture more and have high job satisfaction, comply with isolation precautions more (Erden et al., 2015). It is thought that the nurses with high professional attitudes have a positive effect on the compliance of nurses with the isolation precautions since they have a higher job satisfaction and feel more responsibility for increasing the patient safety and improving the quality of care provided.

\section{CONCLUSION AND RECOMMENDATIONS}

According to the results obtained from the study, it was seen that, although nurses received in-service training on isolation precautions, their compliance was above average, and nurses working in intensive care units showed more compliance with isolation precautions. In the study, it was determined that the professional attitude score of the nurses was high, and some sociodemographic characteristics of the nurses affect their professional attitudes. Furthermore, a significant, positive and weak relationship was found between the professional professional attitudes of nurses and the compliance with isolation precautions.

Keeping professionalism high, which affects performance and efficiency, will enable to improve the quality of care and compliance of healthcare staff with isolation precautions. Increasing motivation of staff, regulating working conditions and planning qualified training programs will affect professional behavior. In order to ensure and increase the compliance of nurses with isolation measures, it is recommended for hospital management and nursing services management to organize training programs and to make sure that all healthcare professionals participate in these trainings. In addition, observational studies on this subject can be combined with qualitative studies and the experiences of nurses in compliance with isolation measures can be revealed in depth. It is also recommended to carry out studies in different hospitals and with larger sample sizes in terms of many variables such as institutional infrastructure, quality studies, satisfaction notifications/rates of individuals and administrative processes that may affect compliance with isolation measures.

\section{LiMiTATIONS}

Conducting the study in a single university hospital, not including private and public hospitals, and interpretation of the results based on the statements of the nurses comprises the limitation of the study.

\section{DECLARATIONS CONFLICTS OF INTEREST}

The authors declare no conflict of interest.

\section{FUNDING}

The study did not receive funding. 


\section{REFERENCES}

Abukan P., Tuncer İE., Ural O., \& Çağlayan V. (2016). Evaluation of knowledge about hospital infections among hospital staff, research assistants, nurses and cleaning staff of Selcuk University Faculty of Medicine. Journal of General Medicine, 26(1),14-18.

Ağırbaș, İ., Akbulut, Y., Azap, A., Çiftçi, E.,Önder, Ö.R., \& Doğanay Payzıner, P. (2015). Sağlık bakımı ile ilișkili infeksiyonların maliyet analizi, Ankara Üniversitesi Tıp Fakültesi Mecmuası, 68(2),71-76. doi:10.1501/Tipfak_000000892

Alkan Çeviker S., Simavlıŏlu G., \& Çetinkaya S.(2019). Yoğun bakımlarda görev yapan hemşirelerinin izolasyon yöntemleri hakkında bilgi ve tutumlarının araştırılması. 6. Uluslararası 17. Ulusal Hemşirelik Kongresi Özet Kitabı. 19-21 Aralık 2019. Ankara. 299.

Allen S., \& Cronin SN. (2012). Improving staff compliance with isolation precautions through use of an educational intervention and behavioral contract. Dimens Crit Care Nurs.31(5),290-94. doi: 10.1097/DCC.0b013e31826199e8.

Alotaibi MM, Almasari SM, Alkadam AN, Alanazi YA, \& Al Gahtani KA. (2017). Knowledge and compliance with standard isolation precautions among healthcare students in Al-Kharj Governorate, Saudi Arabia. $J$ Health Spec, 5(3),162-70. doi:10.4103/jhs.jhs_94_16

Arli Karadağ Ş., \& Bakan Berivan A. (2017). Nurses' compliance with isolation precautions and the affecting factors. Applied Nursing Research.38, 175-78. doi: 10.1016/j.apnr.2017.10.014.

Çelik, S., \& Hisar, F. (2012). The İnfluence of the professionalism behaviour of nurses working in health institutions on job satisfaction. International Journal of Nursing Practice, 18(2), 180-87. doi: 10.1111/j.1440-172X.2012.02019.x.

Çelik, B.,̇̉brahimoğlu, Ö.,\& Mersin, S. (2020). Sağlık profesyonellerinde tükenmişliğin sağlık hizmeti ilişkili enfeksiyonlar üzerine etkisi,Türkiye Sağllk Bilimleri ve Araştırmaları Dergisi 3(1), 61-68.

Doost F.T., Moghadas T., Momeni M., \& Rafiei H. (2016). Factor in fluencing professionalism: a cross sectional study among Iranian registered nurses. Journal of Nursing and Health Science, 5(3), 47-49.

Erbil N., \& Bakır A. (2009). Meslekte profesyonel tutum envanterinin geliştirilmesi. developing inventory of professional attitude at occupation. Uluslararast Insan Bilimleri Dergisi, 6(1), 290-302.

Erden S., Bayrak Kahraman B., \& Bulut H. (2015). Evaluation of compliance of physicians and nurses with isolation precautions in intensive care units. Gümüsshane University Journal of Health Sciences,4(3), 388- 398.

Erol F, \& Türk G. (2019). Assessing the caring behaviours and occupational professional attitudes of nurses. $J$ Pak Med Assoc, 69(6),783-787

Ghadirian F., Salsali M., \& Cheraghi MA. (2014). Nursing professionalism: an evolutionary concept analysis. Iranian Journal of Nursing and Midwifery Research, 19(1),1-10.

Health care-associated Infections. WHO, 2020. Available from:https://www.healthypeople.gov/2020/topicsobjectives/topic/healthcare-associated-infections

Karadağ A., Hisar F., \& Elbaş NÖ. (2007). The level of professionalism among nurses in Turkey. Journal of Nursing Scholarship, 39(4),371-74. doi:10.1111/j.1547-5069.2007.00195.

Karahan E., Taşdemir N., \& Çelik S.(2019). Factors influencing compliance with 1solation precautions among nurses who work in Turkish surgical clinics. Int J Med Invest., 8(2),31-39.

Kaushal G, Doke P, Shah A, \& Verma V. (2015). An analysis of knowledge, attitude and practices regarding standard precautions of infection control and impact of knowledge and attitude of ICU nurses on selfreported practices of infection Control. International Journal of Research Foundation of Hospital and Healthcare Administration, 3(2),79-85. doi: 10.5005/jp-journals-10035-1041.

Kirtil İ, \& Akyüz N.(2018). Precautions taken by nurses about the prevention of hospital-acquired infections in intensive care units. Pak J Med Sci. 34(2), 399-404. doi: 10.12669/pjms.342.14610

Lindberg M, Skytt B, \& LindbergM. (2019). Perceptions of infection control practices and the use of vignettes to alter infection control behavior: A feasibility study. FNJN Florence Nightingale Journal of Nursing,27(3), 231-240.

Lobo D., Martha Sams L., \& Fernandez SL. (2019). Correlation between health professionals' knowledge, attitude and practice about infection control measures. J Med Allied Sci, 9(1):26-31.

Lombarts KMJMH, Plochg T, Thompson CA, \& Arah OA. (2014). Measuring Professionalism in Medicine and Nursing: Results of a European Survey. PLOS ONE, 9(5),e97069. doi:10.1371/journal.pone.0097069.

Mohammadzadeh M, Behnaz F, \& Parsa S. (2013). Knowledge, practice and attitude towards standard isolation precautions in nurses, auxiliary nurses and midwives of Shahid Sadoughi Hospital, Yazd, Iran. International Journal of Infection Control, 9(1),1-8. doi: 10.3396/ijic.v9i1.005.13

Özden D, Özveren H. (2016). Hemşirelerin izolasyon önlemlerine uyumunda mesleki ve kurumsal faktörlerin belirlenmesi. Hemşirelik Akademik Araştırma Dergisi, 2(1),24-32. doi:10.5222/jaren.2016.024. 
Pereira FMV, Malaguti-Toffano SE, Silva AM, Canini SRMS, \& Gir E. (2013). Adherence to standard precautions of nurses working in intensive care at a university hospital. Revista da Escola de Enfermagem de USP, 47(3), 686-93. doi:10.1590/S0080-623420130000300023

Suliman M., Aloush S., Aljezawi M., \& Albashtawy M. (2018). Knowledge and practices of isolation precautions among nurses in Jordan. American Journal Of Infection Control, 46(6),680-684.

Şatır Güleç D., Güneri Er S., Öztürk R., Bülbül Maraş G., Mertoğlu A., \& Sevil Ü. (2019). Evaluating the compliance and factors affecting with 1solation precautions of nurses: Izmir Sample. Journal of Tepecik Education and Research Hospital, 29(3), 218-222.

Tanaka M., Taketomi K., Yonemitsu Y., \& Kawamoto R. (2015). Professional behaviours and factors contributing to nursing professionalism among nurse managers. Journal of Nursing Management,

24,12- 20.

Tayran N.,\& Ulupınar S. (2011). Development of a scale study: validity and reliability of a scale compliance with isolation precautions. Istanbul University Journal of Florence Nightingale School Nursing,19(2),89-98.

Ten Hoeve Y, Jansen G, \& Roodbo P. (2014). The nursing profession: public image, self-concept and professional identity. A discussion paper. Journal of Advanced Nursing, 70(2), 295-309. doi: $10.1111 /$ jan. 12177

Thu T., Anh N., Chau N., \& Hung N. (2012). Knowledge, attitude and practices regarding standard and isolation precautions among Vietnamese health care workers: A multicenter cross-sectional survey. Intern Med,2(4),1-5. doi:10.4172/2165-8048.1000115

Yıldırım N., Tapan B., Gayef A., Sezen A., Alıcı S., \& Kayan Tapan T.(2015). Applications for the prevention of nosocomial infections and a hospital practice. Journal of Tepecik Education And Research Hospital, 25(2),93-100-126.

Zengin M., Yayan EH., Yıldırım N., Akın E., \& Mamiş E.(2018). Effect of professional values upon professional attitudes of pediatrıc nurses. Sağllk Bilimleri ve Meslekleri Dergisi, 5(3),316-323. 